\title{
CYBERSHAMING: THE SHALLOWING HYPOTHESIS IN ACTION
}

\author{
William Stanley Pendergrass, American Public UniversitySystem,william.pendergrass@mycampus.apus.edu \\ Carrie A. Payne, Penn State University, cap15@psu.edu \\ Gregory R. Buretz, Liberated Syndication,gregory@buretz.com
}

\begin{abstract}
Once confined to the classroom, playground, or the walk home, bullying has become immediate, constant, and unrelenting through the use of social media and mobile devices. Cybershaming is both perceived social justice and sport to a growing part of the public. Information sharers and gatherers have become more impulsive and reactive; and less introspective, empathetic, and kind, thus feeding the voracious cybershaming trend. In an attempt to understand why and how the cybershaming trend is growing, the researchers examine three recent cases of cybershaming and their fit within Nicholas Carr's Shallowing Hypothesis.
\end{abstract}

Keywords: Cybershaming, Cyberbullying, Shallowing Hypothesis, Shame, Bullying

\section{INTRODUCTION}

The once powerful communication barriers of space and distance are gone. Information is instantly available online; communication is immediate and global. One can easily make connections with perfect strangers and long-lost friends through social media and wireless devices. People hide behind a perceived force field - the computer or mobile device screen. Responses and reactions, based on impulsivity and ethnocentrism rather than sound judgment and compassion, have become common and accepted forms of online communication. This greater access, opportunity for instant gratification, and perceived force field are enabling, and perhaps encouraging bullying.as, society has become faster, quicker, less introspective, less empathetic, and less nice

Once confined to the classroom, playground, or the walk home, bullying has become immediate, constant, and unrelenting. Information sharers and gatherers have become more impulsive and reactive; and less introspective, empathetic, and kind, thus feeding the voracious cybershaming trend. When an individual or organization expresses unpopular beliefs, politically incorrect statements, or even simply uses poor vocabulary or grammar, they are shamed through counter-comments that emote an ever-increasing ball of fury, wrath, and hate.

Why is cybershaming occurring more frequently? Social media norms, or unspoken rules, have shown everyday people that they need not be with such concerned with others react. In an attempt to understand why and how the cybershaming trend is growing, the researchers examine three recent cases of cybershaming.

\section{RESEARCH METHODOLOGY}

This research effort is a continuation of a research project focusing on Internet trends and culture. Over a period of six years, information on various aspects of the Internet and interaction were collected and categorized. The copious amount of secondary data and numerous data thread correlations to be collected proved to be its own unique problem. Therefore, a case study methodology was selected as the method for data analysis. Yin (2009) advanced that "case studies are the preferred method [of analysis] when (a) "how" or "why" questions are being posed, (b) the investigator has little control over events, and (c) the focus is on a contemporary phenomenon within a real-life context" (Yin, 2009, p. 2).

Yin defined three principles of data collection: 1) use multiple, different sources of evidence, 2) create a database of collected material, and 3) maintain a chain of evidence (Yin, 2009, pp. 114 - 124). Multiple sources of evidence were collected in the form of news articles, Twitter posts, Facebook posts, research documents, books, and other 
types of secondary data. An expansive database of material, including timelines of events and sources, served as the chain of support. This data were then separated into categories or bins. In his book Case Study Research: Design and Methods, Yin (2009, p. 131) discusses a 1929 study which benefited from using descriptive bins to sort through a huge amount of collected data. In Middletown: A Study in Modern American Culture, Lynd and Lynd (1929) defined a number of descriptive so that a copious amount of data taken from a small Midwestern city could be anonymized to create an idea of an "average" American city. Much in the same way, a timeline of events linked to Internet searches was created to show trends of relation to cybershaming events.

\section{CYBERSHAMING}

Terms of reference are important to understand the motivation behind the concept of cybershaming, which derives from a process of cyberbullying and associated trolling. Olweus (1994) first introduced the definition of bullying that is often used in the psychology field. Bullying is an intentional act, based on an imbalance of power and repeated (Levy, Cortesi, Gasser, Crowley, Beaton, Casey and Nolan, 2012, p. 1). Intentionality is differentiated from a random or accidental action which could harm someone. The imbalance of power represents the differences between victims and perpetrators in regard to the perpetrators' strength, position, intelligence or popularity (actual or self-perceived). Repetition means that the harmful actions reoccur over a period of time (Levy, et al., 2012, p. 1). Bullying becomes cyberbullying when it involves "information and communication technologies (ICTs) or other types of Internet technologies" (Levy, et al., 2012, p. 1).

The concept of trolling includes a wide range of intentional activities. "Trolling is a spectrum of behaviors. Some trolling is incredibly aggressive, and meets the legal threshold for harassment. Other forms of trolling, i.e., Rickrolling [a bait and switch technique which substitutes a disguised hyperlink to a video of the 1987 Rick Astley song "Never Gonna Give You Up"] are comparatively innocuous. Some trolling is persistent, continuing for weeks or even months, and some is ephemeral, occurring once and then never again" (Phillips, 2015, p. 23).

Cybershaming is a form of trolling that incorporates the episodic use of cyberbullying to draw out and identify an individual in order to highlight the incorrect behavior or attitude from that of the audience (Licht, 2016, p. 1). "An audience is a prerequisite for shame, even if that audience is imagined," and shame "aims to hold individuals to the group standard" (Jacquet, 2015, p. 9). "Shaming... is a form of punishment, and like all punishment, it is used to enforce norms" (Jacquet, 2015, p. 13).

Shame is not only a feeling. It's also a tool - a delicate and sometimes dangerous one - that we can put to use to help solve serious problems. Shaming is a nonviolent form of resistance that anyone can use, and unlike guilt, it can be used to influence the way groups behave - shame can scale. But shaming requires the attention of the audience, and attention is a zero-sum game. (Jacquet, 2015, p. 26)

Thus, cybershaming is shaming via electronic means, just as cyberbullying is bullying via electronic means (Levy, et al., 2012, p. 1). Cybershaming is meant to enforce social norms, be they delineated or perceived. "[It] can slither through the grate of bad behavior because of its intention to get vengeance or to punish. It is common to think that a perpetrator deserves to be shamed and humiliated" (Warner, 2013, p. 1). Cybershaming collectively draws the attention of the audience to a perceived outlier position, action, or intention.

\section{THE SHALLOWING HYPOTHESIS}

Technology and cultural observer, Nicholas Carr, first proposed the concept of the Shallowing Hypothesis in his Pulitzer Prize nominated book, The Shallows (Carr, 2010).

Carr proposes that the frequent use of ultra-brief social media (i.e., media allowing for social interaction and ultra-brief messages such as texts and tweets) promotes rapid and relatively 
shallow thought and is associated with cognitive and moral shallowness. In other words, frequent usage of this type of media will be associated with a decline in the use of reflective thought, a decrease in importance placed on life goals related to morality and aesthetics, and an increase in importance placed on life goals related to hedonism and image. (Annisette, 2015, p.1)

The Internet delivers a constant barrage of information. Social media sites such as Twitter and Facebook provide the perfect platform for quick response, limited length comments to other users. Instead of dwelling on a problem or issue, i.e., "sleeping on it," social media demands an immediate response. "The [Internet's] cacophony of stimuli short-circuits both conscience and unconscious thought, preventing our minds from thinking either deeply or creatively. Our brains turn into simple signal-processing units, quickly shepherding information into consciousness and then back out again" (Carr, 2010, p. 119). The need to continually monitor activity to ensure you remain current with friends and fans, and the demand distracts people from events and people around them. It effectively desensitizes individuals to others around them. "A 'status update' from a friend, co-worker, or favorite celebrity loses its currency within moments of being issued" (Carr, 2010, 158).

In an experiment (Immordino-Yang, 2009, p. 1) conducted at the University of Southern California's Brain and Creativity Institute, researchers found that the human brain reacts relatively quickly to feelings of pain while "the more sophisticated mental process of empathizing with psychological suffering unfolds much more slowly" (Carr, 2010 , p. 221). It takes time for the brain "to transcend the immediate involvement of the body" (Immordino-Yang, 2009 , p. 1) and to begin to understand and to feel "the psychological and moral dimensions of a situation" (Immordino-Yang, 2009, p. 1).

Heavy social media use comes with consequences, not only for those being cybershamed, but also for the cybershamers. A 2016 study (Lin, Sidani, Shensa, Radovic, Miller, Colditz, Hoffman, Giles, and Primack) found that the more time young adults spend on social media, the more depressed they were. A questionnaire was given to a select group of 19 to 32 year olds on their use of: Facebook, YouTube, Twitter, Google Plus, Instagram, Snapchat, Reddit, Tumblr, Pinterest, Vine, and LinkedIn (Lin, et al., 2016, p. 1).

Those who checked social media most frequently throughout the week were 2.7 times more likely to develop depression than those who checked least often. The 1,787 US participants used social media for an average 61 minutes every day, visiting accounts 30 times per week. Of them a quarter were found to have high indicators of depression. (Lewis, 2016, p. 1)

Social media outlets also come with audiences (users), either invited by the user in the form of friendship (Facebook) or followers of someone the user might find interesting (Twitter). Depending on the social media platform, users can vary in age, sex, relationship, etc. ranging from immediate family members to complete strangers and stalkers. A 2010 study by the Center for Journalism and Communication Research at the University of Texas at Austin found that social media users were more extroverted, anxious and worrisome, and more open to new experiences (Correa, 2010, p. 247). Their openness to new experiences was affected by age; younger people were more open to varying perspectives and experiences. "Gender presented another difference among personality traits. While extroverted men and women were both likely to be more frequent users of social media tools, only the men with greater degrees of emotional instability were more regular users" (Correa, 2010, p. 252).

As more and more individuals more easily and cheaply acquire smartphone technology, they are drawn more and more into their universe of apps, social media, and immediate interactivity. The smartphone screen becomes their own "phone world" (Ansari, 2015, p. 31) where they interact with the participants they've included.

Through our phone world we are connected to anyone and everyone in our lives, from parents to a casual acquaintance whom we friend on Facebook. For younger generations, their social lives play out through social media sites like Instagram, Twitter, Tinder, and Facebook as much as through campuses, cafes, and clubs. But in recent years, as more and more adults have begun spending more and more time on their own digital devices, just about everybody with the means to 
buy a device and a data plan has become a hyper-engaged participant in their phone world. (Ansari, 2015, p. 31)

In the "Brexit" vote of June 2016, British voters had the choice to either leave the European Union (British Exit or Brexit) or remain. Nearly $52 \%$ of voters chose to have Great Britain exit the EU. (Jones, 2016, p. 1) Immediately there was stunned realization as few thought that Brexit would be the result. People were so whipped up by the emotions of the claims of benefits of Brexit, many of which were immediately walked back or disavowed by supporters, that they failed to logically consider the actual benefits and costs of the decision.

When our daily lives take place primarily in the digital realm, indifference and ephemerality can sneak their way into arenas where they don't belong. Media culture privileges snark, insult, "drags," and "burns," which is fine for Twitter. But that same attitude has consequences when applied in the concrete world. In some ways, our minds have become materially conditioned to mindless actions - things that can be deleted or edited or ignored. (Bianco, 2016, p. 1)

The Shallowing Hypothesis helps to explain the ferocity and the immediacy of cybershaming along with willful mindlessness to date. As more people can afford access to instantaneous communication and connection-around the clock and around the world - more will see themselves as part of the culture of immediacy and justice. Cybershaming is both perceived social justice and sport to a growing segment of the population. As shown in the following case studies, cybershaming through the Shallowing Hypotheses tenants can destroy lives within only a few hours. Permanent damage to its victims is the legacy of cybershaming events.

\section{CYBERSHAMING VICTIMS}

\section{Justine Sacco}

On December 20, 2013, Justine Sacco was the top public relations person for InterActiveCorp who tweeted the following before boarding a flight to South Africa (Rowles, 2015, p. 1):

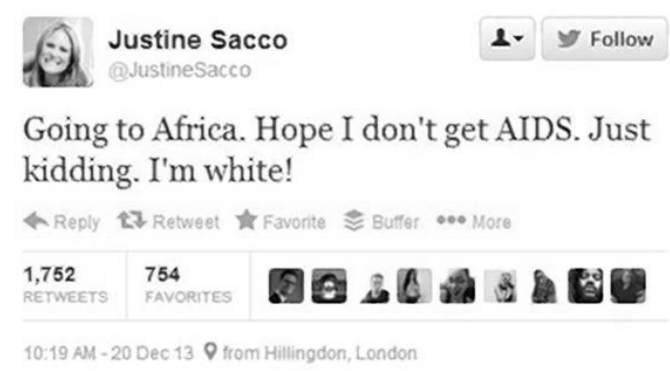

Figure 1. Justine Sacco's Tweet

After boarding the plane, she turned off her cell phone for the 11 - hour flight, knowing nothing of what would quickly unfold around the world.

For the previous two days she'd been tweeting little acerbic jokes to her 170 followers about her holiday travels. She was like a social media Sally Bowles, decadent and flighty and unaware that serious politics were looming. There was her joke about the German man on the plane from New York: "Weird German Dude: You're in first class. It's 2014. Get some deodorant.-Inner monolog as I inhale BO. Thank god for pharmaceuticals." Then the layover at Heathrow: "Chilicucumber sandwiches-bad teeth. Back in London!" Then the final leg: "Going to Africa. Hope I don't get AIDS. Just kidding. I'm white!' (Ronson, 2015a, p. 68) 
The tweet was picked up by Sam Biddle, editor of the Technology page of the now-defunct Gawker Media blog Valleywag which posted gossip and news about Silicon Valley personalities (Biddle, 2013, p. 1). Mr. Biddle retweeted Ms. Sacco's tweet to his many followers, and Buzzfeed, a widely viewed online entertainment website, sparked the viral evolution of the story (Gay, 2013, p. 1). By the time Justine's plane landed in Cape Town, her tweet had been commented on and shared by tens of thousands of Twitter users. There were those who found the tweet offensive for obvious reasons, but there were also those who seemingly enjoyed piling on the event just for the fun of it.

The furor over Sacco's tweet had become not just an ideological crusade against her perceived bigotry but also a form of idle entertainment. Her complete ignorance of her predicament for those 11 hours lent the episode both dramatic irony and a pleasing narrative arc. As Sacco's flight traversed the length of Africa, a hashtag began to trend worldwide: \#HasJustineLandedYet. "Seriously. I just want to go home to go to bed, but everyone at the bar is SO into \#HasJustineLandedYet. Can't look away. Can't leave" and "Right, is there no one in Cape Town going to the airport to tweet her arrival? Come on, Twitter! I'd like pictures \#HasJustineLandedYet." (Ronson, 2015b, p. 1)

When Justine landed and turned on her phone, the Twitter feed from her account began to constantly buzz from all the activity over those 11 hours. She had to turn off her phone and her friend deleted her Twitter account; by that time the damage had been done, and nothing really gets deleted from the Internet. Someone who had followed the storm arrived at the Cape Town airport, and photographed and tweeted her picture to the world. The next day, Justine was fired by InterActiveCorp. They released the following statement regarding the event:

The offensive comment does not reflect the views and values of IAC. We take this issue very seriously, and we have parted ways with the employee in question. There is no excuse for the hateful statements that have been made and we condemn them unequivocally. We hope, however, that time and action, and the forgiving human spirit, will not result in the wholesale condemnation of an individual who we have otherwise known to be a decent person at core. (Biddle, 2013, p. 1)

The irony of the situation is that while Justine's offensive comment did not express any sympathy for those she joked about, those who cybershamed her expressed no sympathy for her. They showed no sympathy for the one they were condemning for showing no sympathy; evidence of the Shallowing Hypothesis' effects.

\section{Walter Palmer}

In July 2015, full-time Minnesota dentist and part-time big game hunter Walter Palmer traveled to Zimbabwe to bag a lion. After filling out the proper government forms (hunting lions is not illegal in Zimbabwe outside of nature preserves) and paying a fee of $\$ 50,000$, with the help of his Zimbabwean guide, they found, tracked, and eventually killed a large adult male lion. Little did they know at the time, it was not just any lion, but a rather famous lion who also had a name given to him by area conservationists: Cecil was a major tourist attraction in Hwange National Park, his home. The 13 year old animal was renowned for being friendly toward tourists and was instantly recognizable because of his large size and distinctive black mane. (BBC News, 2015c, p. 1)

As details of the hunt were made public, the outrage and cybershaming along with physical shaming grew and grew. Walter Palmer did not kill Cecil on Hwange National Park land, which would have been illegal. Instead, Cecil was lured across the border to a private landowner's ranch, and when Cecil was not killed outright by the first arrow, he had to be tracked down only to die 40 hours later from a bullet. All the while, Cecil was wearing a GPS collar which should have been apparent to all participants (BBC News, 2015b, p. 1). 


\section{Issues in Information Systems}

Volume 17, Issue II, pp. 65-75, 2016

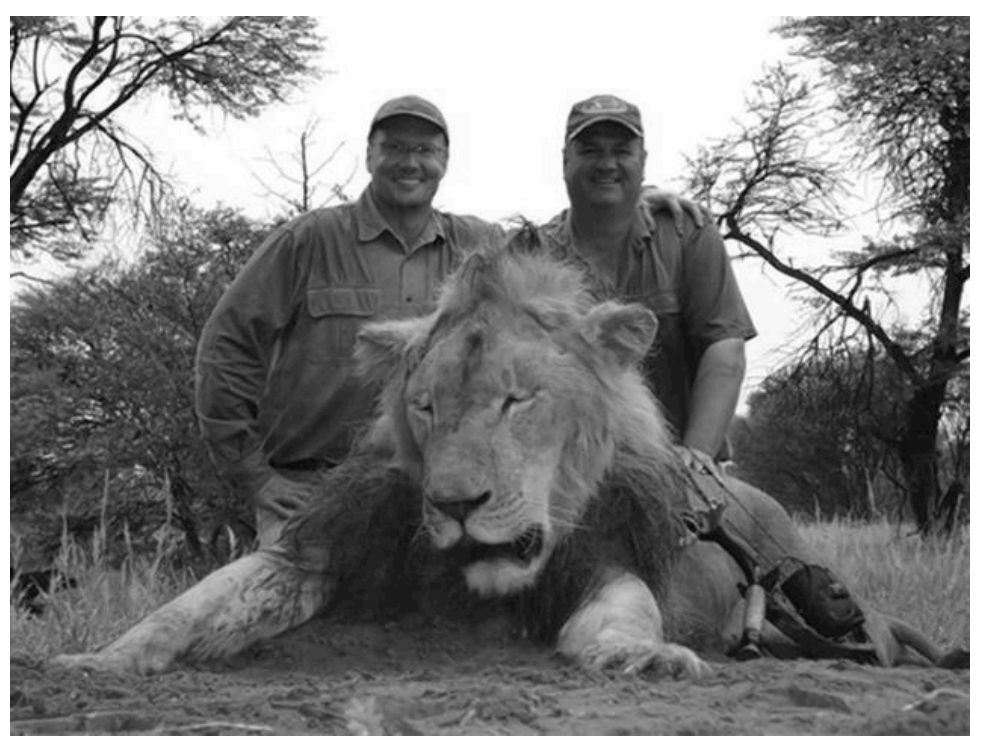

Figure 2. Walter Palmer (left) and Zimbabwean guide Theo Bronkhurst pose behind the body of Cecil the Lion

After news of the hunt was released to the public and Palmer had left the country, Zimbabwean officials arrested the landowner and the guide. They were charged with illegally luring Cecil off protected lands for the purpose of a hunt. Palmer maintained that he did not know the hunt was illegal, nor that the lion he killed had a tracking collar, or was part of a study; however, in the eyes of impassioned online commentators and celebrity tweeters, Palmer was an "instant villain" (Regan, 2015, p. 1).

Everything changed on July 28, when nighttime talk-show host Jimmy Kimmel delivered an emotional monologue about MAGM1, using the lion's nickname: Cecil. The trophy hunter who'd killed him, a Minnesota dentist named Walter Palmer, had been publicly identified the day before, and Kimmel urged viewers to "show the world not all Americans are like this jackhole." Kimmel directed them to the website of the University of Oxford research project that had studied Cecil and his peers since 1999, the Wildlife Conservation Unit, or WildCRU. Within an hour, 4.4 million hits had caused the WildCRU and Oxford sites to crash. For the next week, the unit's head, biologist David Macdonald, did nonstop phone, Skype and TV interviews in the garden outside his offices while a backlog of more than 240 requests grew in his inbox. At the same time, outrage about Cecil's killing spread like a contagion across traditional and social media: On July 29 , more than 99,000 articles and social media posts about Cecil were published, according to a new paper by Macdonald and his colleagues. (Brulliard, 2016, p. 1)

The outraged public began to search social media for Palmer's dental office websites to express their growing rage. People for the Ethical Treatment of Animals (PETA) called for him "to be extradited, charged, and, preferably, hanged" (Miller, 2015, p. 1). A petition was created calling for the White House to extradite Palmer to Zimbabwe to stand trial for the poaching; it quickly exceeded 100,000 signatures (Miller, 2015, p. 1).

Hundreds of - predominantly one-star - reviews have appeared on the Google page for Palmer's dental practice. "Coward" and "Bloodthirsty trophy hunter", they say. "He lured me into his dental practice, then shot me with a bow and arrow," another jokes. The same is happening on Yelp, despite the best efforts of the site to cull the bogus reviews. "Yelp, keep deleting... I'll keep reposting... I have ALL DAY," reads one, adding: "shame on you Walter Palmer". The Facebook page for his practice suffered a similar fate, before being shut down. (BBC News, 2015a, p. 1)

While what Palmer and his accomplices did was illegal in Zimbabwean law and illegal in the worldwide court of public opinion, the flood of cybershaming and rage that befell him quickly grew to the point where not only was his 
practice shuttered for months, but his residence was vandalized and his family threatened. "It's easy to forget just how dangerous and unjust "mob justice" is while it's targeting someone you despise. The more this behavior is normalized, the more likely it is to be deployed against targets who might not necessarily deserve to have their lives destroyed - including, perhaps one day, against you" (Fisher, 2015, p. 1).

In the end, Zimbabwean officials chose not to prosecute Palmer for illegal hunting. In September, 2015, he returned to his dental practice to try and get back to normal. In November, Minnesota state officials investigated Palmer for charges related to "herding" deer onto his hunting land (Dewey, 2015, p. 1). Walter Palmer's cybershaming came with a fury that only killing a much-beloved animal could bring about.

\section{Lindsay Stone}

In October 2012, Lindsay Stone worked for a Massachusetts-based service organization called LIFE (Live Independently Forever), which took care of high-functioning adults with learning disabilities. On a trip to Washington, DC, Jamie Schuh and Lindsay served as guides for a group of LIFE adults sightseeing in the nation's capital (Fox25 WFZT, 2012, p. 1; Zimmerman, 2012).

Off-duty, [Lindsay Stone] and [Lindsay's co-worker] Jamie [Schuh] had a running joke: taking stupid photographs, "smoking in front of a no-smoking sign or posing in front of statues, mimicking the pose. We took dumb pictures all the time. And so at Arlington [the national cemetery] we saw the Silence And Respect sign... and inspiration struck." Lindsey posed in front of it, pretending she was shouting and swearing - flipping the bird, and with her hand to her open mouth. "So," Lindsey said, "thinking we were funny, Jamie posted it on Facebook and tagged me on it with my consent, because I thought it was hilarious" (Fox 25 WFXT, 2012, p. 1; Ronson, 2015c, p. 1).

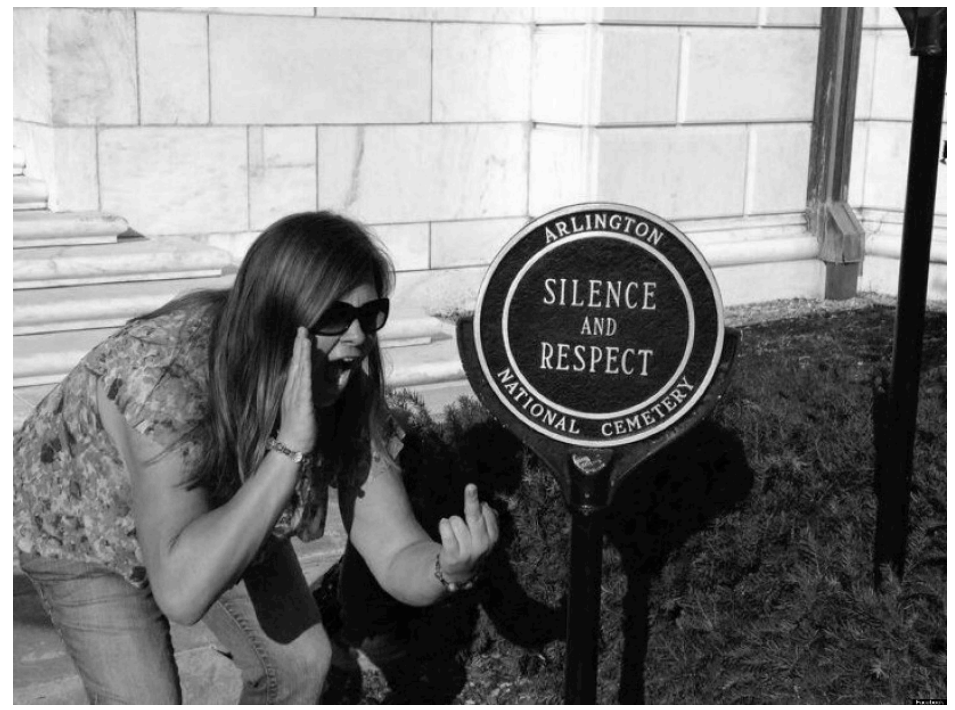

Figure 3. Lindsay Stone's Facebook tagged picture

Initially there was little reaction from the pair's Facebook friends. Some of her friends who were formerly in the military commented that the photograph was in poor taste, but said little more than that. About a month after posting the photograph, Facebook comments on the picture began to take off. "By the time she went to bed that night, at 4am, a Fire Lindsey Stone Facebook page had been created. It attracted 12,000 likes. Lindsey read every comment" (Ronson, 2015c, p. 1). The next day, camera crews showed up outside her door looking for a comment and to try to get an interview from Lindsay. 
LIFE was inundated with requests to have her fired. Her employer eventually gave in to the requests and let her go. "Literally overnight, everything I knew and loved was gone," Lindsey said. And that's when she fell into a depression, became an insomniac, and barely left home for a year" (Ronson, 2015c, p. 1). The question remains: "Should Stone be made to suffer potential unemployability for a bad joke posted on her personal, private Facebook page? For many, it seems the answer is without question, a resounding yes. Not only did over 30,000 voluntarily join a group devoted to her firing (now deleted), but a further 3,000 signed a petition demanding the same" (Zimmerman, 2012, p. 1). The cybershaming and its consequences affected Lindsay deeply. After a period of time she was able to finally get a job but lived in constant fear of being discovered as the girl who flipped off the Tomb of the Unknown Soldier.

\section{CONCLUSIONS}

Cybershaming is the evolution of bullying and cyberbullying; it is a by-product of instant gratification and ideologies and the explosion of social media and instant communication coupled with decreasing empathy. Cybershaming is both perceived social justice and sport to a growing population of social media users. The imbalance of power represents the differences between victims and perpetrators in regard to the perpetrators' strength, position, intelligence or popularity, actual or self-perceived. Cybershaming is often most powerful when it occurs as the perpetrators collectively attack their targets online. Carr's Shallowing Hypothesis helps to explain the ferocity and the immediacy of cybershaming to date. As more people can afford access to instantaneous communication and connection - around the clock and around the world - more will see themselves as part of the culture of immediacy and justice. The more social media enables immediate access to updates and events, the more the thoughtless and non-reflective responses will occur.

By definition, cybershaming is enabled by technology and proliferates through the use of technology. Though, the concept of perceived social justice is one that is not as easily understood. The concept of justice has been debated by philosophers since the dawn of time. What is just? It is subjective. The authors make no claim to whether any of these cybershaming acts were just or whether the only effects were negative.

The future of technological development appears to be increasing exponentially. Along with this increase in development comes a decrease in associated costs per byte. First Generation Cell Phone technology has developed into Fifth Generation Smartphone capability. Nearly every corner of the inhabited globe can now be reached via a Smartphone signal and instantly link up with the Internet. The culture of demanded immediacy is ingrained in technologically-linked individuals. As software and hardware development races on and instant communication becomes faster than instantaneous, the culture will become more and more uncaring and indifferent to the harm it might inflict on perceived heretics and outliers.

\section{FUTURE RESEARCH}

This paper does not examine, in-depth the issues of perceived social justice, ethnocentrism, narcissism, or sociopathy, but these concepts impact the proliferation of cybershaming and trolling incidents. As cybershaming continues to grow and have substantial impacts on the digitally-connected world, the authors surmise that culture, communication, psychology, and sociology researchers (among others) will examine (or continue to examine) the longer-term effects of these cybershaming incidents, in mass and individually. Further, many constitutional scholars and lawmakers will continue to debate what constitutes free speech, harassment, or abuse. The incidents to explore are plentiful, diverse, and interdisciplinary. 


\section{REFERENCES}

Annisette, L, and Lafreniere, K. (2016). Social media, texting, and personality: a test of the shallowing hypothesis. Personality and Individual Differences. http://dx.doi.org/10.1016/j.paid.2016.02.043

Ansari, A. (2015). Modern Romance. New York: Penguin Press

BBC News. (2015a, July 29). How the internet descended on the man who killed Cecil the lion. BBC News. Retrieved from http://www.bbc.com/news/blogs-trending-33694075

BBC News. (2015b, July 30). What Cecil the lion means to Zimbabwe. BBC News. Retrieved from http://www.bbc.com/news/world-africa-33722688

BBC News. (2015c, October 12). Cecil the lion: no charges for Walter Palmer, says Zimbabwe. BBC News. Retrieved from http://www.bbc.com/news/world-africa-34508269

Bianco, M. (2016, June 28). Brexit is what happens when our digital lives seem more "real" to us than our real ones. Quartz. Retrieved from http://qz.com/718197/brexit-is-what-happens-when-our-digital-lives-seemmore-real-to-us-than-our-real-ones/?google_editors_picks=true

Biddle, S. (2013, December 20). And now, a funny holiday joke from IAC's PR boss. Gawker. Retrieved from http://valleywag.gawker.com/and-now-a-funny-holiday-joke-from-iacs-pr-boss-1487284969

Brulliard, K. (2016, May 4). You remember Cecil the lion. But will you recall Scarface, the slain grizzly? The Washington Post. Retrieved from https://www.washingtonpost.com/news/animalia/wp/2016/05/04/youremember-cecil-the-lion-but-will-you-recall-scarface-the-slain-grizzly/

Carr, N. (2010). The Shallows: What the Internet is Doing to Our Brains. New York: W. W. Norton.

Correa, T., Hinsley, A. \& Zuniga, H. (2010). Who interacts on the web?: the intersection of users' personality and social media use. Computers in Human Behavior. 26.

Dewey, C. (2015, December 22). Whatever happened to the 15 people the Internet hated most in 2015? The Washington Post. Retrieved from https://www.washingtonpost.com/news/theintersect/wp/2015/12/22/whatever-happened-to-the-15-people-the-internet-hated-most-in-2015/

Fisher, M. (2015, July 30). From Gamergate to Cecil the lion: internet mob justice is out of control. Vox. Retrieved from http://www.vox.com/2015/7/30/9074865/cecil-lion-palmer-mob-justice

Fox 25 WFXT. (2012, November 21). Mass. woman fired from job following Facebook photo fallout. Fox 25 WFXT. Retrieved from http://www.myfoxboston.com/news/mass-woman-fired-from-job-followingfacebook-photo-fallout-2/139249529

Gay, R. (2013, December 23). Justine Sacco's aftermath: The cost of Twitter outrage. Salon. Retrieved from http://www.salon.com/2013/12/23/justine_saccos_aftermath_the_cost_of_twitter_outrage/

Immordino-Yang, M., McColl, A., Damasio, H. \& Damasio, A. (2009, May 12). Neural correlates of admiration and compassion. Proceedings of the National Academy of Sciences. 106/19.

Jacquet, J. (2015). Is Shame Necessary? New York, NY: Pantheon Books.

Jones, B. (2016, July 1). Brexit: the week that brought Britain to its knees. CNN. Retrieved from http://www.cnn.com/2016/07/01/europe/brexit-one-week-on/ 
Levy, N, Cortesi, S., Gasser, U., Crowley, E., Beaton, M., Casey, J. and Nolan, C. (2012). Bullying in a networked era: a literature review. Kinder \& Braver World Project: Research Series. 2012-17, 1-61. Retrieved from http://ssrn.com/abstract $=2146877$

Lewis, K. (2016, March 24). Heavy social media users 'trapped in endless cycle of depression'. Independent. Retrieved from http://www.independent.co.uk/life-style/health-and-families/health-news/social-mediadepression-facebook-twitter-health-young-study-a6948401.html

Licht, C. (Producer). (2016, March 26). CBS this morning: Saturday. [Television broadcast]. New York, NY: Central Broadcasting Service. Retrieved from http://www.cbsnews.com/videos/the-phenomenon-ofinternet-shaming/

Lin, L., Sidani, J., Shensa, .A.., Radovic, A., Miller, E., Colditz, J., Hoffman, B., Giles, L., and Primack, B. (2016, January 19). Association between social media use and depression among U.S. young adults. Depression and Anxiety. 33: 323-331. doi: 10.1002/da.22466. Retrieved from http://onlinelibrary.wiley.com/doi/10.1002/da.22466/abstract

Lynd, R. \& Lynd, H. (1929). Middletown: A Study in Modern American Culture. New York: Harcourt Brace \& Company.

Miller, M. (2015, July 30). PETA calls for Walter Palmer to be 'hanged' for killing Cecil the lion. The Washington Post. Retrieved from https://www.washingtonpost.com/news/morning-mix/wp/2015/07/30/peta-calls-forwalter-palmer-to-be-hanged-for-killing-cecil-the-lion/

Olweus, D. (1994). Bullying at school: basic facts and effects of a school-based intervention program. Journal of Child Psychology and Psychiatry, 35(7), 1171-1190.

Phillips, Whitney. (2015). This Is Why We Can't Have Nice Things: Mapping the Relationship between Online Trolling and Mainstream Culture. Cambridge, MA: The MIT Press.

Regan, H. (2015, July 30). Cecil the Lion, Walter Palmer and the psychology of online shaming. Time. Retrieved from http://time.com/3978216/online-shaming-social-media-walter-palmer-cecil-lion/

Ronson, J. (2015a). So You've Been Publicly Shamed. New York, NY: Riverhead Books.

Ronson, J. (2015b, February 12). How one stupid Tweet blew up Justine Sacco's life. The New York Times Magazine. Retrieved from http://www.nytimes.com/2015/02/15/magazine/how-one-stupid-tweet-ruinedjustine-saccos-life.html?_r=0

Ronson, J. (2015c, February 21). 'Overnight, everything I loved was gone': the internet shaming of Lindsey Stone. The Guardian. Retrieved from http://www.theguardian.com/technology/2015/feb/21/internet-shaminglindsey-stone-jon-ronson

Rowles, D. (2015, February 17). What happened to Justine Sacco, the woman whose life was ruined by an AIDS joke she made on Twitter? Uproxx. Retrieved from http://uproxx.com/webculture/what-happened-tojustine-sacco-the-woman-whose-life-was-ruined-by-an-aids-joke-she-made-on-twitter/

Warner, R. (2013, August 17). Are public shaming and cyberbullying the same? The Huffington Post. Retrieved from http://www.huffingtonpost.com/russ-warner/are-public-shaming-and-cy_b_3443957.html

Yin, R. (2009). Case Study Research: Design and Methods. Fourth Edition. Thousand Oaks, CA: Sage. 


\section{Issues in Information Systems}

Volume 17, Issue II, pp. 65-75, 2016

Zimmerman, N. (2012, November 22). Happy now?: 'good employee' Lindsey Stone fired over Facebook photo. Gawker. Retrieved from http:/gawker.com/5962796/happy-now-good-employee-lindsey-stone-fired-overfacebook-photo 